\title{
Family perception of humane care provided by health care personnel
}

\author{
Percepción de los familiares acerca de la atención humanizada brindada por el personal de \\ salud
}

\section{Percepção dos parentes sobre o atendimento humanizado fornecido pelo pessoal de saúde}

\author{
Luz Marina Bautista-Rodríguez ${ }^{*}$ \\ Yari Paola García-Calderón ** \\ Lessly Johana Medina-Chaves ${ }^{* * *}$ \\ Karley Ginary Cruz-Hernández $z^{* * * *}$
}

\section{Autor de correspondencia}

* Nurse. Magister in nursing with focus on health services management. Professor Assistant Vice-dean for studies Universidad Francisco de Paula Santander. Email: bautrod@gmail.com. (D) https://orcid.org/00000002-8891-4397. Cúcuta, Colombia.

** Student VIII semester Nursing program. Universidad Francisco de Paula Santander. Email: yaripaolagc@ufps.edu.co. (D) https:// orcid.org/0000-0002-2892-6871. Cúcuta, Colombia.

*** Student VIII semester Nursing program. Universidad Francisco de Paula Santander. Email: lesslyjohanamc@ufps.edu.co. https://orcid.org/0000-0001-6639-9032. Cúcuta, Colombia.

**** Student VIII semester Nursing program. Universidad Francisco de Paula Santander. Email: karleyginarych@ufps.edu.co. (D) https://orcid.org/0000-0001-9978-851X. Cúcuta, Colombia.

\begin{abstract}
Objective: To determine the perception the family has about the humane care in the Intensive Care Units of three Health Service Institutions in the city of Cucuta (Colombia). Materials and Methods: A quantitative cross-sectional descriptive study was performed with a sample of 220 family members that met the requirements of inclusion; for the recollection of the information, the instrument used was denominated Family perception about humanization in the intensive care units, designed and validated in Cucuta by students and teachers of VIII semester from the Nursing Program at the University Francisco de Paula Santander in 2016. To determine the liability the Cronbach's Alpha was used, obtaining a value of 0.89 . Results: The humane care perception by family members was moderate in $63 \%$ of the participants. The communication and information, emotional support and family participation were the highest rating categories, while coping and visits had the lowest ratings. Conclusions: The participants of the study perceive as moderate the humane care, since they relate this to the quality of the care provided, considering the evaluated categories in the research. On the other hand, the family members point out that they receive the necessary information and support to involve themselves in the care activities, allowing them for more interaction with the hospitalized familiar and the personnel.
\end{abstract}

Keywords: Care givers, perception, communication, care humanization, critical care.

\section{Resumen}

Objetivo: Determinar la percepción que tiene la familia acerca de la atención humanizada en las Unidades de Cuidados Intensivos de tres Instituciones Prestadoras de Servicios de Salud de la ciudad de Cúcuta. Materiales y Métodos: Se realizó un estudio cuantitativo de tipo descriptivo de corte transversal con una muestra de 220 familiares que cumplieron

licencia CC BY

(https://creativecommons.org/

licenses $/$ by $/ 4.0 /$ ) (c) () 
los requisitos de inclusión; para la recolección de la información se utilizó el instrumento denominado Percepción de los familiares acerca de la humanización en las unidades de cuidados intensivos, diseñado y validado en Cúcuta por estudiantes y docentes de VIII semestre del Programa de Enfermería de la Universidad Francisco de Paula Santander durante el año 2016. Para determinar la confiabilidad se utilizó el alfa de Cronbach, obteniéndose un valor de 0.89. Resultados: La percepción de la atención humanizada por parte de los familiares fue moderada en el $63 \%$ de los participantes, la comunicación e información, el apoyo emocional y la participación familiar fueron las categorías con mejor calificación, mientras que el afrontamiento y las visitas tuvieron los valores más bajos de calificación. Conclusiones: Los participantes del estudio perciben como moderada la atención humanizada, puesto que la relacionan con la calidad de la atención que les brindan, teniendo en cuenta las categorías evaluadas en la investigación. Por otra parte, los familiares señalan que reciben información y apoyo necesario para involucrarse en las actividades de cuidado, permitiéndoles una mayor interacción con el familiar hospitalizado y el personal.

Palabras Claves: Cuidadores, percepción, comunicación, humanización de la atención, cuidados críticos.

\section{Resumo}

Objetivo: Determinar a percepção que tem a família sobre atendimento humanizado nas Unidades de Terapia Intensiva (UTI) de três instituições que prestam serviços de saúde na cidade de Cúcuta. Materiais e Métodos: Realizou-se um estudo quantitativo de tipo descritivo de corte transversal com uma amostra de 220 parentes que preencheram os requisitos de inclusão; para a recolecção da informação se utilizou o instrumento denominado: "Percepção dos parentes sobre a humanização nas unidades de terapia intensiva", desenhado e validado em Cúcuta por estudantes e docentes de VIII semestre do Curso de Enfermagem da Universidad Francisco de Paula Santander durante o ano 2016. Para determinar a confiabilidade se utilizou o alfa de Cronbach, obtivendo-se um valor de 0,89. Resultados: A percepção do atendimento humanizado por parte dos parentes foi moderada no $63 \%$ dos participantes, a comunicação e informação, o apoio emocional e a participação familiar foram as categorias com melhor qualificação, enquanto que o afrontamento e as visitas tiveram os valores mais baixos de qualificação. Conclusões: Os participantes do estudo percebem como moderado o atendimento humanizado, já que o relacionam com a qualidade do atendimento que lhes oferecem, tendo em conta as categorias avaliadas na pesquisa. Por outra parte, os parentes apontam que recebem informação e apoio necessário para involucrar-se nas atividades de cuidado, permitindo-lhes uma maior interação com o parente hospitalizado e o pessoal de saúde.

Palavras-chave: Cuidadores, percepção, comunicação, humanização do atendimento, terapia intensiva.

\section{Introduction}

When talking about humanization it is necessary to talk about health quality. The Pan-American Health Organization assumes that "quality is doing what is correct the first time and doing it better the next, with the limitations of the existing resources and the community satisfaction" (1). In Colombia, the Social Protection Ministry through the General System of Social Security for Health, (SGSSS), incorporated quality as the fundamental principle of the health public service, which can be considered as the care provided to the patient according to scientific evidence, given in a comprehensive, safe and appropriate manner, through humane care (2).
It is convenient to highlight that satisfaction of the user begins at the moment in which the person comes into contact with the provider until the care concludes; in this interaction there are some unique characteristics from quality that determine its approval, corresponding to the way that users perceive it, relating to the manner on how they can access and make use of the services. Also, time has to be considered, the promptness of response, how they are treated, the information offered, among others. Through the aforementioned parameters it is possible to identify and measure the expectations and necessities users request in a subjective manner such as inherent and desirable qualities of care, as well as objective measures established to get data about their behavior (2). 
ISSN-PRINT

1794-9831

E-ISSN 2322-7028

Vol. 15 No. 2

Jul - Dic 2018

Cúcuta, Colombia
Note that internationally there are reviews about quality. In 2013, the United States described its strategy of National Quality as: "the quality in health improved by $60 \%$ through the patient and family centered care, making sure that family members are included in the care process" (3). On a national level, the experience of care is evaluated through the perception of satisfaction of the users; the numbers show that in 2014, Colombia, 7-8 out of 100 users, both in IPS (health facilities) and in Administrative Entities of Benefit Plans $(E A B P)$ considered that their expectations were satisfied (4).

On the other hand, within the reviewed literature, theoretical foundations relating to humanization can be found. For instance, the caring theory proposes a model where caring and healing practices will take all health professionals (doctors, nurses, psychologists, etc.) generally speaking, beyond the healing focus, situating caring and healing practices in a paradigm that recognizes the relationship between humanitytechnology-nature-universe, as established by Watson (5). From this point of view, human sciences are considered as important as scientific sciences; that is to say, that although human sciences are often forgotten in the professional training, these allow the comprehension of the social, cultural and psychological dynamics of people. For Watson the process of caring generates an interpersonal relationship based on the mutual feelings of help and trust the nurse-patient experience, having a phenomenological context of human care where nurses must consider the ten caring factors (6).

It is important to know, that in the framework of this context, the problematic about quality in relation to the humanization and therefore to satisfaction has been raised. In Colombia, the Colombian Institute of Technical Standards and Certification (ICONTEC), within the accreditation axis of health, highlights the humanization of care, making an emphasis on the humanization care policies that the health facilities must have. These policies should always be focused on human dignity though aspects such as privacy, confidentiality and visiting hours according to: the necessities and preferences of the patient, management of given information, comfort conditions, technology with opportune care, reduction of waiting time, etc. (7).

When integrating the guidelines proposed by ICONTEC, the Ministry of Social Protection and other entities created the accreditation manual of health through the resolution 000123 in January of 2012, this incorporates new specific standards of humanization, promotion and prevention. Accordingly, it is emphasized the centered attention both in the patients and their family, being coherent with the sociodemographic and cultural characteristics, as well as with their necessities (8).

On a regional level, the Development Plan for North of Santander contemplates the promotion of humane care in its central theme "support and strengthening of lifetime" through training workshops for State institutions; this way, facilitating the humanization of services and the effective enjoyment of the right to public health. In the same way, different IPS (health facilities) in the city of Cucuta have the incentive to implement the humanization of care to their services through awareness and training; however, implementing humane care in all services and institutions is an arduous job that requires time, as well as constant studies and research $(9,10)$.

It should be noted that for private IPS in the city, it is fundamental to acknowledge the necessary aspects of humanization relating to the interaction of family members and the health personnel, allowing the compliance of national and international policies; this way the ICU becomes a place in which humanization activities are promoted and strengthened every day.

It is to note, that the admission of a person to the ICU implies a situation of crisis, a stressing event that generates an impact in the life of both the patients and their family. When a member of the family has a medical condition, the rest of the family are affected, causing in these latter mentioned emotional instability, guilt, anxiety, preoccupation, irritability, frustration, depression and uncertainty; in this context, humane care by the health personnel is necessary, since they have the capability to reduce these negative effects, becoming a protective factor, generating a comforting and supporting environment; for this reason, it is necessary that the families and the patients get the opportunity to express their feelings and make questions since its their right to know what is happening $(1,11,12)$.

While it is true that for a long time, health attention revolved around the patient exclusively as the central subject who required immediate care, currently the emphasis has been on inclusive care for the family. It 
has also been proven that family members are affected by the medical condition of their dear ones; also, there are records about physical and psychological problems such as stress, uncertainty, anxiousness, among others and their decrease or increase mostly relies on the actions taken by the health personnel towards family members (13). If a family member is well informed about the situation and the prediction of the patient, he or she will be more than likely prepared to confront a difficult situation $(2,14,15)$. Considering the previously proposed, some of the characteristics that direct to the humanization of care processes can be enumerated: continuous improvement of procedures, assertive communication with the health personnel, information, perceived support, and visits in the health facilities (2). It is convenient to note, that humanization should be a compromise with the user in an ethical sense; therefore, it is responsibility of the directives of the institution to reflect it as a policy of organization, regarding this subject, Quintero et al. (16) affirm that "the health personnel must provide humane care of excellence to honor the human being, as well as conserving and/or improving health" (17).

Humanizing the ICU requires of various studies about the means, the reflection and the consensus of the implied sanitary professionals considering multiple aspects relating to the cultural, physical and organizational variables. The health personnel must have extraordinary qualities that allow them to provide consoling and emotional support to the patients and their family; this part is considered as fundamental in their labor, as well as alleviating the suffering by promoting trust values for the patients to be able to cope with their medical condition, and stay at the hospital; equally important, aspects of organization must improve to achieve a more comfortable and humane ICU (18).

Certainly, family participation requires coupling and intervention of one or various dear ones, suggested in a progressive manner and directed by the interdisciplinary team, depending on the state and the possibility of the patient, this way giving a more humane significance to caring. Achury and Achury (19) in their study based on the Human Becoming Theory of Rosemarie Parse, describe the great influence the environment has in the health of the patients, in this case, their families; it is said that family members must assume a more active participation in the medical condition of the patient at the ICU, being able to bring a series of basic care, under the orientation of health personnel, with them facilitating a state of comfort (19).

As a result of the considerations previously mentioned, it is necessary to redirect the concept of humanization in the care of the patient and family. For this reason, the continuous loss of humanization of care must be avoided, since it is a decisive aspect for satisfaction; it is impossible to pretend to care for a person when their dignity is not considered, nor their feeling or emotions are respected. The humanization of care is fundamental in the quality of Health institutions. It is in the hands of the health personnel to provide care with greater attributes that meet the expectations of the patients and their families.

On the other hand, the professional exercise as a nurse in Colombia in the context of the Law of Social Security for Health must be dynamic and respond to the changing necessities not only of the users, but also of the family members; these latter demand education, support, information, spiritual support and orientation to accept the crisis that generates having a family member at the ICU. In that sense, although the study is performed on all health personnel for the Nursing profession, it is crucial to know the perceptions and necessities of the family, aspects which allow to orientate the support that can be provided to the family members of these type of patients.

In attention to the exposed previously, the purposes of this study are: to determine from a dynamic and human prospective the perceived aspects by the family of the patients as relevant to provide comprehensive humane care; giving a diagnosis of the care provided by the health personnel, and subsequently offering them parameters, strengths and weaknesses of their care, this way allowing them to rethink, improve and determine some of the weaknesses-strengths of the institutions regarding this matter, which is useful for the development of improvement programs.

\section{Materials and Methods}

A quantitative cross-sectional descriptive study was performed. The population subject of research was composed by 549 family members of hospitalized users at the ICU of the three institutional health service providers (IPS) of III and IV level in Cucuta during the first semester of 2017. The sample was 
composed of 226 family members; the selection was done through an aleatory stratified sampling for convenience. Subjects that met the following criteria were considered: family members of first level of consanguinity (parents, spouse, children, siblings) that were present during the visiting hours, people over 18 to 60 years old, people with an Intensive Care Unit stay of the patient for at least one week.

On the other hand, for the recollection of information the instrument used was a scale denominated Family Perception about the Humanization at the Intensive Care Units; this instrument was designed and validated by teachers and students of VIII semester from the Nursing program in 2016 (20); it is characterized for being simple, understandable, and easy to use. This instrument allows us to recognize the family perception in relation to the humane care according to the categories: family participation, communication and information, coping, emotional support, and visits. The legitimacy of the content and the reliability of the instrument was conducted by the authors, through a group of experts and over the application of the pilot test performed on families of hospitalized patients at the ICU of other Health Service Institutions in the city of Cucuta. For the reliability the Cronbach Alpha was used, obtaining 0.89 , which indicates that the scale is consistent.

The collected information was reviewed and verified to identify the complete fulfillment of requirements of each instrument. Subsequently, the data was put into Excel to then be used in tables and graphs that represent absolute and relative frequencies.

It must be specified that in the present research the do no harm principles, justice, charity, autonomy and confidentiality ethics are guaranteed. For being a research of low risk, the free will and the information of the interviewed was obtained verbally (Article 16 Resolution 08432 of 1993) once the subjects were informed about the justification, objectives, procedure to recollect information, inconveniences and benefits of the research. The suspension of the interview or the participation in the study was guaranteed to each participant during the development of the research.

Furthermore, administrative paperwork was made in the three institutions following the established policies in each one to obtain the correspondent permissions for the recollection of the information. In one of the institutions, the authorization was done through the Ethics committee according to the Certificate 00389 of April 4, 2017. The other two institutions obtained their approval through letters from the Education and Service Committee.

\section{Objectives}

\section{General objective}

Determine the perception of the family about the humane care at the ICU of three Health Service Institutions in Cucuta during the first semester of 2017.

\section{Specific objectives}

- Socio-demographically characterize the population subject of study.

- To Identify family involvement of caregivers of hospitalized patients at the ICU.

- Describe the communication provided to the family of the hospitalized patient at the ICU.

- Identify the coping that the family members of the hospitalized patient have to face.

- Describe the emotional support provided to family members of the hospitalized patients at the ICU.

- Describe the visits made by family of the hospitalized patients at the ICU.

\section{Results}

The research was performed during the first semester of 2017 between February and May. The recollection of the information was taken by researchers during visiting hours, according to the availability of the family members. The total number of people that participated in the study was 226 , which met the inclusion criteria.

The population subject of study was composed by: $60.4 \%$ of females, between the ages of 35 and 45 , mostly married, of social stratus level 2 (40.9\%) with high school level of education; regarding consanguinity, $34 \%$ of the family corresponded to children, followed by husband or wife.

\section{Family perception about family participation}


The perception in relation to the participation of the family was measured by the application of 11 items with a maximum scoring of 33 points; it was found that in the three institutions, proposed activities are performed permanently in various items of this category, observing that the more frequent are: $94 \%$ who make the induction course during the admission to the ICU, and $90 \%$ participates in the decision taking about important procedures and treatments with the hospitalized person. On the other hand, it stands out that in some aspects like opportune care of the concerns and permanently communicating were valued with the scale as "sometimes", based on important elements for the family of the hospitalized patient, as it can be observed in Table 1 .

Table 1. Relation of the valued aspects in the category Family Participation. Intensive Care Units. Institutional Health Service Providers. Cucuta. 2017.

\begin{tabular}{|c|c|c|c|}
\hline Aspects & Never & Sometimes & Always \\
\hline Provide an induction the first time of admission to the ICU & $0.5 \%$ & $5.5 \%$ & $94 \%$ \\
\hline Affect the personal relationships with the family member & $29.1 \%$ & $32.3 \%$ & $38.6 \%$ \\
\hline Participate in the care & $7.3 \%$ & $22.7 \%$ & $70 \%$ \\
\hline Family importance for the recovery of the patient & $2.1 \%$ & $25.3 \%$ & $72.6 \%$ \\
\hline Provide confidence and support to participate in the care & $2.1 \%$ & $22.1 \%$ & $75.8 \%$ \\
\hline Provide education and/ or information at the moment of performing care & $3 \%$ & $24.9 \%$ & $72.1 \%$ \\
\hline Communication with the health personnel & $8.5 \%$ & $33.9 \%$ & $57.6 \%$ \\
\hline $\begin{array}{l}\text { Participating in the decisions about the important procedures and } \\
\text { treatments }\end{array}$ & $0.8 \%$ & $8.5 \%$ & $90.7 \%$ \\
\hline Opportune care of concerns & $2.1 \%$ & $48.5 \%$ & $49.4 \%$ \\
\hline $\begin{array}{l}\text { Inadequate treatment by the health personnel when performing activities } \\
\text { with the patient }\end{array}$ & $59 \%$ & $31 \%$ & $10 \%$ \\
\hline Tiredness of visiting the patient at the ICU & $69.3 \%$ & $24.9 \%$ & $5.8 \%$ \\
\hline
\end{tabular}

Source: Scale of Perception of family about the humanization at the Intensive Care Units (PFH) 2017.

\section{Family perception about communication and} information

The communication and information category is composed of 9 items which allow the perception the family has about this factor. The maximum scoring is 27 points, as it can be observed is Table 2. The aspects of major relevance for the family are related to $80.4 \%$ of verbal information and $65.4 \%$ of written information that are provided during the visit about the evolution of the patient and the procedures to be performed on the patient.

Table 2. Relation of the valued aspects in the communication and information category. ICU in the Health Service Institutions. Cucuta 2017.

\begin{tabular}{lccc}
\hline \multicolumn{1}{c}{ Aspects } & Never & Sometimes & Always \\
\hline Report about the health status of the patient & $4.3 \%$ & $21.2 \%$ & $74.5 \%$ \\
Use understandable vocabulary & $11.5 \%$ & $31.3 \%$ & $57.2 \%$ \\
Report of each procedure to be performed on the patient & $11 \%$ & $15 \%$ & $74 \%$ \\
Report about the evolution of the patient during visits & $10.5 \%$ & $7.7 \%$ & $81.8 \%$ \\
\hline Attitude of the personnel when providing information & $25.1 \%$ & $12.7 \%$ & $62.2 \%$ \\
Verbal information provided by the personnel & $6.8 \%$ & $12.8 \%$ & $80.4 \%$ \\
Written information provided by the personnel & $18.3 \%$ & $16.3 \%$ & $65.4 \%$ \\
Time dedicated to provide information & $29.2 \%$ & $32.7 \%$ & $38.1 \%$ \\
\hline Physical contact during the conversation & $23.8 \%$ & $42.2 \%$ & $34 \%$ \\
\hline
\end{tabular}

Source: Scale of Perception of family about humanization of the Intensive Care Units (PFH) 2017. 
ISSN-PRINT

1794-9831

E-ISSN 2322-7028

Vol. 15 No. 2

Jul - Dic 2018

Cúcuta, Colombia

\section{Family perception about coping}

Coping is evaluated through 9 items that allow to explore the used resources by each institution to address the crisis and the stress that hospitalization at the ICU of a family member generates in the family. The maximum scoring was 27 points; in this category, it is observed the perception of negative aspects specified as follows:
$71.73 \%$ of the family members are not satisfied with the psychological support provided by the health personnel; $68.3 \%$ of family members perceived that family was not allowed to have reunions to strengthen emotions; $67.9 \%$ did not have a place where they could express their feelings; and $68.6 \%$ did not get offered the psychology service to care for the patient and family (table 3 ).

Table 3. Relation of the aspects evaluated in the coping category. ICU Health Service Institutions. Cucuta. 2017.

\begin{tabular}{|c|c|c|c|}
\hline Aspects & Never & Sometimes & Always \\
\hline Admission of religious support during visiting hours & $42.2 \%$ & $19.1 \%$ & $38.7 \%$ \\
\hline Undestanding and acceptance of the medical condition process of the patient & $25.5 \%$ & $19.5 \%$ & $55 \%$ \\
\hline Receving help to control and/or decrease negative feelings & $13.7 \%$ & $29.5 \%$ & $56.8 \%$ \\
\hline Allowing family reunions with the patient to strengthen emotions & $68.3 \%$ & $21.4 \%$ & $10.3 \%$ \\
\hline Provide spaces to express feelings & $67.9 \%$ & $25.9 \%$ & $6.2 \%$ \\
\hline Provide measures to minimize stress & $29.2 \%$ & $28.1 \%$ & $42.7 \%$ \\
\hline Provide psycological support & $71.3 \%$ & $23.7 \%$ & $5 \%$ \\
\hline Offer psycology service & $68.6 \%$ & $13.2 \%$ & $18.2 \%$ \\
\hline Receive spiritual support & $37.8 \%$ & $49.1 \%$ & $13.1 \%$ \\
\hline
\end{tabular}

Source: Scale of Perception of family about humanization of the Intensive Care Units (PFH) 2017.

\section{Family perception about emotional support}

The perception of emotional support is measured through the revision of 14 items with a maximum scoring of 42 points; in this category positive elements were found: $82 \%$ considers that the health personnel inspires confidence, $80 \%$ indicates that safeness is provided when communicating with their family, and $73 \%$ recognizes that family spiritual necessities are respected; likewise, they expressed feeling calmness when the personnel look at their face when communicating. On the other hand, some negative aspects are: $18 \%$ of the personnel that work at the institutions never consider the emotional state of the patient's family visitor.

\section{Family perception regarding visits}

The results obtained in the visit category can be observed in Table 4. This category is evaluated through 8 items with a maximum scoring of 24 . According to the results obtained in the research, it was found that $96.3 \%$ of family members feel content with the care provided by the personnel during visits and feel satisfied when visiting the patient; on the other hand, $82 \%$ express that the time of visit designated by the institution is met; and $79.4 \%$ manifests feeling comfortable in the physical spaces destined for this purpose. Likewise, some aspects require improvement such as: admission of children in exceptional cases; accepting admission twice a day to the ICU; and finally, authorizing the admission of multiple family members at the same time for special cases.

Table 4. Relation of the aspects evaluated in the visits category. ICU Health Service Institutions. Cucuta. 2017.

\begin{tabular}{lccc}
\hline \multicolumn{1}{c}{ Aspects } & Never & Sometimes & Always \\
\hline Allowing the admission of family members more than once a day & $68 \%$ & $19 \%$ & $13 \%$ \\
Allowing the admission of multiple family members at the same time dur- & $78 \%$ & $18 \%$ & $4 \%$ \\
ing visiting hours & $5 \%$ & $13 \%$ & $82 \%$ \\
Allowing to fulfill the stipulated time of visit & $98.2 \%$ & $1.1 \%$ & $0.7 \%$ \\
Allowing the admission of children to the ICU in exceptional cases & $3.3 \%$ & $17.3 \%$ & $79.4 \%$ \\
Comfortability in the spaces designated for visits & $1 \%$ & $24 \%$ & $75 \%$ \\
Offering other spaces for family visits & $0.6 \%$ & $3.1 \%$ & $96.3 \%$ \\
Feeling satified when visiting & $0.90 \%$ & $3.1 \%$ & $96 \%$ \\
\hline Feeling content with the care provided by the health personnel
\end{tabular}

Source: Scale of Perception of family about humanization of the Intensive Care Units (PFH) 2017. 


\section{General family perception about humane care}

When evaluating the general perception of the families of hospitalized patients at the Intensive Care Units, it is perceived that $63 \%$ experience it as moderate. It is evidenced that as a whole, interviewed family members coincide in that aspects regarding humanization are positive in all the categories proposed by the researchers. The categories with the highest rating were: emotional support, communication and information, and family participation; while coping and visits had the lowest ratings of the evaluation performed on the population subject of study.

\section{Discussion}

The supportive social network is composed by the relations an individual can establish with people in the disease process. It is of vital importance having multiple people with the capacity to know and perform the required care with the necessary affection, this allows to cope with the situation of current medical condition.

During the present study, it was confirmed that the accompaniment of family members of first level of consanguinity (children, spouse) and women is predominant. Similar results are found by different researchers where it is noted that although there are social transformations and changes on the role of women in society, they continue to perform the role of caregiver that has been evidenced throughout history, this privileges their attention to the care of the patient as well as solving their physiological, emotional, spiritual, and wellness necessities (21-24).

\section{Family Participation}

Family participation is vital for the development of each persona and even more necessary when the individual is going through an adverse situation, in this case close family and friends who offer unconditional support. Family generally meets economic, educative, social and psychological functions, factors that are fundamental for the development of human beings; likewise, these components will be of positive use for social integration after the experience at the ICU. It is important to consider that when a family member is admitted to the Intensive Care Unit, the person suffers a structural and emotional crisis, this alters their interaction and relationship with their family; this situation creates important changes depending on the type of disease and its prognosis (25). In this environment, the role of the family is fundamental and essential with everything relating to the necessary actions to satisfy the basic needs and care of the patient, their final objective is to help with the recovery of the patient; similarly, they should demonstrate interest in learning the recommendations and lessons given by the health personnel in the interest of performing the adequate care (26). As referred by Zomeño (27):

"If the family context is not considered, in occasions, the health personnel will be limited to have a wider understanding of the patient and therefore it will be much harder to satisfy all the individual need to enhance the wellness of the patient".

In the study of Ramirez and Parra(28), they recommend the personnel to make an effort to integrate family with the basic care of the patient, contemplating on the fundamental role the family has in the emotional component, since family is considered to be the only nexus with the outside. Also, Melendez et al. (29) were able to proof the interest family has on involving themselves in the care of the patient since family members expressed being the ones that knew the patient better and therefore were more suitable to provide emotional support.

According to the bibliographical review, it can be concluded that the results obtained in other studies give great importance to family participation, in virtue of having more clear information about the service and the health situation of the patient $(30,31)$; however, it must be noted that Martos et al. (32) found different results, demonstrating that $85.9 \%$ of family members with a patient at ICU that were admitted for the first time to the service, did not receive relevant information about the existing equipment and alarms.

\section{Communication and Information}

For an adequate communication is necessary the use of a similar or equal code; from this point of view a code is understood as a set of standards, images, gestures, language, etc. which serve to transmit the message. The communication process will be influenced by diverse factors inherent to speaker and receptor, among others, their culture, attitude or their level of instruction about the subject. It is important to note that communication pretends to provide adequate and relevant information to the family with the purpose of maintaining a conversational environment, always 
ISSN-PRINT

1794-9831

E-ISSN 2322-7028

Vol. 15 No. 2

Jul - Dic 2018

Cúcuta, Colombia transmitting the meaning and sense of the reality the family is in, reducing the uncertainty and increasing the knowledge about the health situation of the patient (33). It is also important that the participant family members feel satisfied with the information verbally provided about the health situation of the patient when the doctors properly explain about the procedures to be performed, as well as the evolution of the patient; thus, family will minimize anxiety and uncertainty that rises when a family member is hospitalized at the ICU. It should be considered that this type of communication must be done through simple words and be accompanied by an adequate attitude by the speaker

Nonverbal communication must be considered also, relating to behaviors such as: the capability of the health personnel to express their feelings and encourage empathy and family confidence throughout symbolic language, appearance, posture, facies, voice tone, gestures, as well as patience when responding, and maintaining eye contact when talking to the family member (34). Families manifested that the health personnel does not provide at any moment physical contact, such as shoulder tapping during conversations, this being a demonstration of hope, with the purpose of feeling more relaxed and less anxious. It must be considered that these types of gestures can make the person feel understood; in other words, a warn and trustful relationship must me provided, which eases the family to express and share their feelings.

It is important to highlight that the results obtained in this research, with relation to the relevance of communication in the interaction of the family of the patient at the ICU are similar to the ones found in other studies, where the importance of providing clear information about the health situation of the patient in a simple and understandable way $(35,36)$.

It should be emphasized that in the health area, verbal and nonverbal communication are considered essential to establish a proper therapeutic relationship between the health personnel-patient-family, as manifested by Ramirez et al. (37):

"Communication must have the intention of transmitting the adequate information, clear and relevant to the family as well as creating a conversational environment, this way reducing uncertainty in the family and increasing the knowledge about the health situation of the patient".

It is worth highlighting that for the relevance communication currently has on Health Institutions to obtain excellent care and humanization quality, it is required that the personnel has the appropriate and pertinent education that facilitates the family interaction in relation to: the empathy, active listening, ease to express themselves, sensibility in relation to the interests of the family and the capability of explain themselves, etc. These are the fundamental elements of the professionals of the health area with the purpose of them being able to establish an effective communication with the family of the hospitalized patient at the ICU, as Escudero et al. (38) and Pardavila and Vivar suggest (35).

Furthermore, the information and communication provided to the family must be considered as one of the principal needs, since it must supply adequate and opportune information in specific subjects related to the care provided to the patient, as set out by Marquez and Carrillo (39), "it has been found that the family demands access to information, particularly about the prognosis, the progress from treatment, handling methods and the care supplied by the health personnel". From there is concluded the need to provide the family with clear, simple, understandable and relevant information about the situation of the patient, becoming a significant component to achieve the active participation and the satisfaction of the family.

\section{Coping}

The experience of having a family member hospitalized at the ICU generates an alteration of the family dynamics, causing crisis and instability in each member of the family. From this perspective, changes in the family routine should be considered a result of the lack of knowledge of the health prognosis of the patient; these alterations have to do with: anxiety, fear produced by the situation, the type of service and the equipment surrounding the patient, factor that produce stress, which is why it is fundamental that the health personnel supports the family, for them to be able to understand and accept the disease process of the patients and their recovery; as mentioned by Lindarte et al. (20) "the hospitalization in the ICU is a traumatic stress, since it subdues the family members 
to a difficult situation generating a change of roles, movement from home to the ICU, and fear of death"; for this reason, family is obligated to combine their feelings of uncertainty with the comprehension of the explanations provided, taking difficult decisions and in occasions, the acceptance of the inevitable $(39,40)$.

On the other hand, family coping is presented as an effort to understand the events affecting the family to decide a specific action. Parting from the idea in which processes of interaction are determined by the roles each of the family members represent, and the mutual expectations of the family, it is supposed that the family adapts to the ICU scenery; that is to say, understanding and accommodating to the particularities of this service, such as: restrictions, visiting limitations, use of devices and equipment for the patient, and the perception of a risk environment and of possible death, etc (39).

Regarding the positive aspects found in the present study, it can be noted that the interviewed family members demonstrated their gratitude to the health personnel for the respect shown towards the family beliefs, by allowing the admission of people who provided religious support to the ICU; this strategy was used as a coping mechanism. As stated by Tarquino (41) "for the family, religious and spiritual beliefs serve as a coping mechanism of the stressing event". It is important to highlight that this kind of support allows the family to adapt better, understand the disease process at the ICU and count with the necessary resources to face unexpected outcomes.

\section{Emotional support}

The World Health Organization (WHO), defines family as the members of the family who are directly related; thus, in a family, the members interact by performing different roles surging from individual and group needs in their surroundings (parents, children etc.). For this reason, the disease of a family member can generate relevant changes, causing a high risk of maladjustment in the family, provoking crisis, stress, consternation, frustration, becoming an experience that is emotionally painful and requires support by the health personnel $(42,43)$.

Also, emotional support implies an attitude of empathy that predisposes the professional to care about the feelings, desires, thoughts, interests, needs and experiences of the patient. Therefore, the health personnel must be the support who can provide the patient tranquility and wellness through active listening, presence, friendly conversations, demonstration of feelings and performing care with a natural attitude $(44,45)$.

Likewise, it can be assumed that health personnel of the Intensive Care Units in the participant Institutions of this study provide confidence and safety to the families of the hospitalized patients, generating wellness, respectful relationships and capability to interact on behalf of the patient; as it is well known, these elements are fundamental for humane care and at the same time are indispensable characteristics in the relationship that the personnel must establish with the patients and their families, as stated by Muñoz et al. (46) "the helping relationship consists on establishing throughout material, relational, and technical resources, a therapeutic relationship with the patient to cope with the problems in a healthy way.

According to this research, the results obtained are similar to the ones found by other researchers, where it is emphasized that actions relating to empathy, trust, accompaniment during medical procedures, providing tranquility, loving care, respect, comprehension, solidarity, providing care based on emotional support, etc., allow a better interaction with the family in relation to questions, doubts and preocupations (28, $35,47)$.

\section{Visits}

Visits can be defined as "the moment which allow close family and friends to be with the hospitalized patient, accomplishing better welfare and the early recovery of the patient. Visits become a fundamental tool which allows to satisfy the social, emotional, informational and accompanying needs of the patient" (48).

Considering the results obtained in this research, family manifest feeling content during the visit, referring to the interaction the personnel, physical space destined for this purpose and the role they perform as caregivers, generating satisfaction when visiting the hospitalized family member and a better perception of the care quality, as expressed by Achury et al. (49), who found in their study that family visits offer benefits to the patient, the family and the health personnel. In the specific case of the family, an increase of the satisfaction of their needs is allowed, since they have a greater chance to know and receive 
ISSN-PRINT

1794-9831

E-ISSN 2322-7028

Vol. 15 No. 2

Jul - Dic 2018

Cúcuta, Colombia more information by the interdisciplinary team about the health situation of the patient $(19,36)$.

Therefore, "the visits must be then, the space to provide the necessary education and information that allow the integration and help for the care of the critical patient, also considering the constant evaluations and assessments of the responses obtained of both the patient and the family to be able to adopt the required actions in case such reactions are negative. Similarly, visits must have flexible times that allow the health personnel to provide as much information and education as possible, this way obtaining greater benefits for the patient (20)". On the other hand, for the family, time during the visit becomes vital, since they must get the maximum Benefit from the visit at the ICU, considering that it is the moment where family can communicate with the health personnel and accompany the patient.

It should be stressed, in function to the findings of this research that some aspects should be strengthened: allowing the admission of children in exceptional cases, authorizing the admission twice a day to the ICU, as well as, authorizing the admission of multiple family members at the same time in exceptional cases. Therefore, the care services in the ICU must implement flexible visits to allow the family sharing time, feeling useful and involving themselves in the care the patient needs. Ultimately, the recovery of the patient will be faster if the family is well informed about the health situation., in other words, if flexible visits are the efficient method to satisfy the needs of the patient (50).

\section{Perception about humane care}

The perception of humane care by the family is conceived as a "mental and cognitive process of the family, that consists on the recognition, interpretation and significance of humanization through physical or human tools granted by the Health Institution, allowing the users to create appreciation about their participation in the care of the patient $(28,31)$ ". In that sense, the perception understands the appreciation given by the family of the hospitalized patient at the ICU about humane care, based on the satisfaction of the family with the service offered, considering the existence of certain factors that determine the perception, making it different from one person to another.
According to the results obtained, it is concluded that the families of the patients at the participant ICU of this study, perceive as moderate the humane care, relating this to the quality of the care provided, the emotional support offered, the information about the health situation of the patient, the opportunity to participate in the care of the patient, and visits. Also, an aggregate value is observed in the attitudes and behavior the health personnel takes and their capability to communicate and be sensitive to the need of the patients and their families. On the other hand, its valid to highlight the categories with the highest rating, which were related to: emotional support, communication and information, and family participation; factors that evidence that the relationship between the health personnel and the family is of vital importance for the development of actions for the benefit of the health situation of the patient and to understand the current health situation of the hospitalized patient.

Likewise, it was evidenced that the Health Institutions with Intensive Care services must analyze the different variables that contribute to humane care with the purpose of achieving the implementation of improvement plans to strengthen the interaction with the family, generating a more flexible visit environment, closeness, comprehension, and affection. Also, a context of reflection and feedback must be encouraged to allow the personnel to reinforce their required capabilities to achieve an effective interpersonal relationship, though the permanent consolidation of change for the benefit of a quality care culture based on humanization.

\section{Conclusions}

- Obtaining the perception of the family about the humane care as moderate indicates that, although pertinent action is taken to strengthen the quality, it can be improved. The flexible visits, and emotional and spiritual support are influential aspects of the key role the family must have in the Intensive Care Services.

- In general, family perceive that there is active participation, they receive the necessary information and support to involve themselves in the care activities and this way contribute to the recovery of the patient; however, in some cases the interpersonal relationships of the health personnel who work in 
the Intensive Care services must be reinforced.

- The information and communication of the family has a great aggregate value, since they consider this as one of the important aspects to be aware of: the health situation of the patient, the procedure, the treatments, the evolution, etc. The satisfaction of the family mostly relies on these variables; from there, it is necessary to have adequate, relevant, understandable, and simple information, which is vital for the psychological health and the satisfaction of the family of the critical patient.

- Similarly, it is required that Health Institutions develop actions that allow the strengthening of the family, to understand and cope with the health situation in a service of critical care. In that sense, psychological and spiritual support must be considered, as well as, a positive and adequate management of these to face the critical situation of the hospitalized family member.

- The interviewed family members expressed in their responses that the health personnel inspire in them trust, highlighting empathy, confident attitudes when asking concerns about the patient, effective communication and respect towards religious beliefs; these are determining factors that contribute to the reinforcement of the emotional support the family requires for this stressing situation. Also, it is important to note that the nursing personnel as well as the health team, is privileged for staying as long as possible with the patient and the family, thus allowing a strengthening of the comprehensive care quality, which is focused in humanization.

\section{Bibliographic References}

1. Forrellat M. Calidad en los servicios de salud: un reto ineludible. Rev Cubana Hematología, Inmunología y Hemoterapia. 2014; 30(2):179-183.

2. Andrade Pérez CE, Gómez Forero LA. Oportunidad en la prestación de servicios de salud en urgencias 24 horas de una IPS de nivel i en Santiago de Cali 2012-2013. [Tesis Maestría]. Colombia: Universidad del Valle; 2014. [consultado el 25 de Noviembre de 2017]. Disponible en: http://bibliotecadigital.univalle. edu.co/bitstream/10893/8755/1/OPORTUNIDAD\%20EN\%20LA\%20PRESTACI\%C3\%93N\%20 DE\%20SERVICIOS\%20DE\%20SALUD\%20EN\%20URGENCIAS\%2024.pdf

3. National Healthcare Quality and Disparities Report and 5th Anniversary Update on the National Quality Strategy. [Internet]. 2015 [Consultado el 3 de Marzo de 2017]. Disponible en: https://www. ahrq.gov/research/findings/nhqrdr/nhqdr15/priorities.html

4. Así vamos en Salud. Seguimiento a la salud en Colombia. Indicadores de Salud. Tasa de Satisfacción Global EAPB/IPS. [Internet]. 2016. [Consultado el 03 de Marzo de 2017]. Disponible en: http://www. asivamosensalud.org/indicadores/servicios-de-salud/tasa-de-satisfaccion-global-eapbips

5. Watson J. Watson's theory of human caring and subjective living experiences: carative factors/caritas processes as a disciplinary guide to the professional nursing practic. Texto \& Contexto Enfermagem 2007; 16(1):129-135.

6. Favero L, Freitag Pagliuca LM, Ribeiro Lacerda M. Transpersonal caring in nursing: an analysis grounded in a conceptual model. Rev Esc Enferm USP 2013; 47(2):489-494.

7. Instituto Colombiano de Normas Técnicas y Certificación, ICONTEC. Humanización de la atención. Ejes de acreditación [Internet]. 2016. [Consultado el 19 de Mayo de 2017]. Disponible en http://www. acreditacionensalud.org.co/ea/Paginas/HumAte.aspx

8. República de Colombia. Ministerio de Salud y Protección social. Resolución № 000123 de 2012, enero 26, por la cual se modifica el artículo 2 de la Resolución 1445 de 2006 [Internet]. Bogotá, D.C: El ministerio; 2012 [Consultado el 19 de Mayo de 2017]. Disponible en: http://www.acreditacionensalud. org.co/sua/Documents/Res123\%20ene26de2012\%20modificRes1445.pdf

9. Gobernación de Norte de Santander. Plan de Desarrollo para Norte de Santander 2016-2019 “Un 
ISSN-PRINT

1794-9831

E-ISSN 2322-7028

Vol. 15 No. 2

Jul - Dic 2018

Cúcuta, Colombia

Norte Productivo Para Todos”. [Internet] San José de Cúcuta: el Gobernador; 2016. [Consultado el 19 de Mayo de 2017]. Disponible en: http://www.sisubregionalns.gov.co/files/sid_Desarrollo territorial/ Plan_de desarrollo para_Norte de Santander_2016-2019.pdf

10. Clínica Norte. Programa de humanización de la unidad de cuidados intensivos Clínica Norte S.A. [Internet]. San José de Cúcuta; 2016. [Consultado el 19 de mayo 2017] Disponible en: http://www. clinicanorte.com.co/politica-de-humanizacion-de-la-unidad-de-cuidados-intensivos/

11. Asmet Salud EPS. Humanización de los servicios de salud [Internet]. Popayán; 2014. [Consultado el 1 de mayo de 2017]. Disponible en: http://www.asmetsalud.org.co/news/show/title/humanizacion-delos-servicios-de-salud

12. Chávez Cruz AL, Molina Regalado JL. Evaluación de la calidad de atención en salud mediante el modelo de Avedis Donabedian, en el área de emergencia del Hospital Paravida de Julio a Diciembre 2014. [Tesis Maestría]. El Salvador: Universidad del Salvador; 2015. [consultado el 25 de Noviembre de 2017]. Disponible en: http://ri.ues.edu.sv/11055/

13. Shaw DJ, Davidson JE, Smilde RI, Sondoozi, Agan D. Multidisciplinary team training to enhance family communication in the ICU. Crit Care Med 2014; 42(2):265-271.

14. Galvis López CR, Salamanca Ramos E. Percepción de necesidades en cuidadores familiares de adultos internados en una unidad de cuidados intensivos de una institución prestadora de salud (IPS) privada en Villavicencio, Colombia. Rev Investigación en Enfermería: Imagen y Desarrollo [Internet]. 2014 [consultado el 25 de Noviembre de 2017]; 16(2):81-94. Disponible en: http://www.redalyc.org/ articulo.oa? id=145232887006

15. Fernández Sotelo S. Las necesidades de los familiares del paciente crítico en una Unidad de Cuidados Intensivos [Tesis en Internet], España: Universidad Da Coruña; 2015. [Consultado el 26 de Noviembre de 2017]. Disponible en: http://ruc.udc.es/dspace/bitstream/handle/2183/15330/Fernandez Saida TFG 2015.pdf; sequence $=2$

16. Quintero A, Maldonado M, Guevara B, Delgado C. Cuidado humanizado como esencia en el profesional de Enfermería. Revista Médica Electrónica [Internet]. 2015 [Consultado el 22 de marzo de 2017]. Disponible en: http://www.revista-portalesmedicos.com/revista-medica/cuidado-humanizadoenfermeria/

17. Benjamín O, Vargas Rozo G. La Medición de la Percepción de la Calidad de los Servicios Odontológicos como Herramienta para su Mejoramiento. Aplicación en las Clínicas Odontológicas Integradas de Bogotá. [Tesis Maestría]. Colombia: Universidad Nacional de Colombia; 2016. [Consultado el 25 de Noviembre de 2017]. Disponible en: http://www.bdigital.unal.edu.co/52178/1/tfobgvr2016.pdf

18. Sandoval Guerrero JL. Abrir las mentes primero y, después, las puertas de las UCI. Med Intensiva [Internet]. 2016 [Consultado el 20 de abril de 2017]; 40(3):197-200. Disponible en: http://www. medintensiva.org/es/abrir-las-mentes-primero-y/articulo/S0210569116000036/

19. Achury Saldaña DA, Archury Beltrán LF. Participación familiar en el cuidado de pacientes críticos: una propuesta de fundamentación teórica. Investigación en Enfermería: Imagen y Desarrollo [Internet]. 2013 [Consultado el 16 de marzo de 2017]; 15(2):137-151. Disponible en: http://revistas.javeriana. edu.co/index.php/imagenydesarrollo/article/download/7073/5620

20. Lindarte Vega DY, Florez Uribe E, Cantor Barajas MF, Rincón Manrique SL, Acevedo Barrera SP. Percepción de los familiares acerca de la humanización en las unidades de cuidado intensivo en tres IPS de la ciudad de Cúcuta. Cúcuta: Universidad Francisco de Paula Santander ; 2017.

21. Martínez L, Araiza A, Garay AI, Peñaranda MC. Género, espacio doméstico y socialización del cuidado: algunas perspectivas de cambio. International Journal of Developmental and Educational Psychology 2011; 5(1):181-186.

22. Nieves Rico M, Robles C. Políticas de cuidado en América Latina Forjando la igualdad. Serie Asuntos de género No 140. Comisión Económica para América Latina y el Caribe (CEPAL). [Internet]. 
[Consultado el 24 de noviembre de 2017]; Santiago: Publicación de las Naciones Unidas; 2016. Disponible en: http://repositorio.cepal.org/bitstream/handle/11362/40628/1/S1600887 es.pdf

23. Martínez Lupi FL. Significado de Cuidado y proyecto de vida de mujeres cuidadoras de personas con diagnóstico de Parkinson. [Tesis Maestría]. Uruguay: Universidad de la República de Uruguay; 2015. [Consultado el 25 de Noviembre de 2017]. Disponible en: https://sifp.psico.edu.uy/sites/default/files/ Trabajos\%20finales/\%20Archivos/tfg 30 de julio $0 . p d f$

24. Comas D'Argemir D. Los cuidados de larga duración y el cuarto pilar del sistema de bienestar. Rev Antropología Social 2015; 24:375-404.

25. Cid Rodríguez MC, Montes Oca Ramos R, Hernández Díaz O. La familia en el cuidado de la salud. Rev. Médica Electrónica. [Internet]. 2014 [Consultado el 05 de marzo de 2017]; 36(4): 462-472. Disponible en: http://scielo.sld.cu/scielo.php?script=sci_arttext\&pid=S1684-18242014000400008\&lng=es

26. Bernal Ruiza D, Horta Buitrago S. Cuidado de enfermería para la familia del paciente crítico desde la teoría de la comprensión facilitada. Enfermería Universitaria 2014; 11(4):154-163

27. Zomeño Ross G. Incorporación del familiar del enfermo hospitalizado a los cuidados enfermeros intrahospitalarios. [Tesis Doctoral] España: Universidad de Alicante; 2015 [Consultado el 22 de abril de 2017]. Disponible en: https://rua.ua.es/dspace/bitstream/10045/47031/1/tesis ginesa zome $\% \mathrm{C} 3 \% \mathrm{~B} 10$ ros.pdf

28. Ramírez Perdomo CA, Parra Vargas M. Percepción de los comportamientos del cuidado de enfermería en la unidad de cuidados intensivos. Avances en Enfermería [Internet]. 2011 [Consultado el 01 de marzo de 2017]; 29(1):97-108. Disponible en: http://revistas.unal.edu.co/index.php/avenferm/article/ view/35861/37067

29. Meléndez F, Héctor J, Fernández F. Mortalidad general y atribuible a cuidado intensivo: estudio de cohorte. Acta Colombiana de Cuidado Intensivo [Internet]. 2011 [Consultado el 16 de febrero de 2017]; 11(2): 91-99. Disponible en: http://www.amci.org.co/institucional-4/revista/suplementos/2011

30. Ballesteros Pinzón GA. Comunicación entre la enfermera y el familiar de la persona hospitalizada en la unidad de cuidados intensivos. [Tesis Maestría]. Colombia: Universidad Nacional de Colombia; 2014. [Consultado el 25 de Noviembre de 2017]. Disponible en: http://www.bdigital.unal.edu. co/47111/1/91506989.2014.pdf

31. Celis Hernández MJ, Gutiérrez Guarín N, Iregui Jones LL. Percepción de la familia frente al rol de enfermería en la unidad de cuidado intensivo adulto de la fundación Cardiovascular de Colombia. [Tesis Internet]. Colombia: Universidad de Bucaramanga; 2015 [Consultado el 16 de marzo de 2017]. Disponible en: http://bdigital.ces.edu.co:8080/repositorio/bitstream/10946/4288/1/Percepcion Familia Enfermeria.pdf

32. Martos Casado G, Aragón López A, Gutiérrez Ramos N. Satisfacción de los familiares de los pacientes ingresados en una unidad de cuidados intensivos: percepción de los familiares y los profesionales. Enferm Intensiva [Internet]. 2014 [Consultado el 01 de mayo de 2017]; 25(4):164-172. Disponible en: http://www.elsevier.es/es-revista-enfermeria-intensiva-142-articulo-satisfaccion-los-familiareslospacientes-S1130239914000741

33. Ruiz Casado M. La comunicación como herramienta básica de enfermería. [Tesis en Internet], España: Universidad de Valladolid; 2015. [Consultado el 25 de Noviembre de 2017]. Disponible en: https:// uvadoc.uva.es/bitstream/10324/13605/1/TFG-O\%20567.pdf

34. Alarcón Rincón L, Serrato Triana SA. Implementación de una guía de comunicación para los pacientes con ventilación invasiva conscientes en la unidad de cuidado intensivo. [Tesis Especialización]. Colombia: Universidad de Nacional de Colombia; 2014. [Consultado el 25 de Noviembre de 2017]. Disponible en: http://www.bdigital.unal.edu.co/43076/1/1076651617.2014.pdf

35. Pardavila Belio MI, Vivar CG. Necesidades de la familia en las unidades de cuidados intensivos. Enferm Intensiva [Internet]. 2012 [Consultado el 01 de marzo de 2017]; 23(2):51-67. Disponible 
ISSN-PRINT

1794-9831

E-ISSN 2322-7028

Vol. 15 No. 2

Jul - Dic 2018

Cúcuta, Colombia

en: $\quad$ http://www.elsevier.es/es-revista-enfermeria-intensiva-142-articulo-necesidades-familia-lasunidades-cuidados-S1130239911000460

36. Riley BH, White J, Graham S, Alexandrov A. Traditional/restrictive vs patient-centered intensive care unit visitation: perceptions of patients' family members, physicians, and nurses. PubMed [Internet]. 2014 [Consultado el 01 de mayo de 2017]; 23(4):316-324. Disponible en: https://www.ncbi.nlm.nih. gov/pubmed $/ 24986172$

37. Ramírez Arias JL, Ocampo Lujano R, Pérez Páez I, Velázquez Trinidad D, Yarza Solórzano ME. La importancia de la comunicación efectiva como factor de calidad y seguridad en la atención médica. Acta Médica Grupo Ángeles. 2011; 9(3):167-174

38. Escudero D, Viña L, Calleja C. Por una UCI de puertas abiertas, más confortable y humana. Es tiempo de cambio. Med Intensiva [Internet]. 2014 [Consultado el 18 de febrero 2017]; 38(6):371375 Disponible en: http://www.medintensiva.org/es/por-una-uci-puertas-abiertas/articulo/ $\underline{\mathrm{S} 0210569114000370 /}$

39. Márquez Herrera M, Carrillo González GM. La experiencia del familiar de la unidad de cuidados intensivos en Bucaramanga (Colombia): un estudio fenomenológico. Archivos de Medicina (Col) [Internet]. 2015 [Consultado el 27 de abril de 2017]; 15(1):95-106. Disponible en: http://www.redalyc. org/pdf/2738/273840435010.pdf

40. Martín Díaz MD, Jiménez Sánchez MP, Fernández Abascal EG. Estudio sobre la escala de estilos y estrategias de afrontamiento. Revista Electrónica de Motivación y Emoción [Internet] 2000. [Consultado el 24 de abril de 2017]; 3(4) Disponible en: http://reme.uji.es/articulos/ agarce $4960806100 /$ texto.html

41. Tarquino Díaz LJ. La familia del paciente en unidad de cuidado intensivo (uci). [Tesis en Internet]. Bogotá: Universidad del Rosario; 2014.

42. Bernal Ruíz D, Horta Buitrago S. Cuidado de enfermería para la familia del paciente crítico desde la teoría de la comprensión facilitada. Enf Universitaria. [Internet] 2014 [consultado 20 Noviembre 2016]; 11(4):154-163. Disponible en: http://www.sciencedirect.com/science/article/pii/ $\underline{\text { S1665706314709285 }}$

43. Gómez Gómez LL. El paciente critico en la UCI: saber comunicarse con él y su familia. [Tesis en Internet], España: Universidad Internacional de Catalunya; 2015. [Consultado el 25 de Noviembre de 2017]. Disponible en: http://www.recercat.cat/bitstream/handle/2072/25926/Llu\%C3\%ADs_G\%C3\% B3mez_G\%C3\%B3mez.pdf?sequence $=1$

44. González Naranjo D, Lescaille Palu M. Reflexión, desde la óptica del cuidado cultural. Rev Cubana Enfermer [Internet]. 2013 [consultado el 25 de Noviembre de 2017]; 29(2):60-62.

45. Martín Muñoz B, Montesinos Gálvez AC. Ayuda emocional entre pacientes ostomizados. Biblioteca Las Casas. [Internet]. 2011 [Consultado el 16 marzo de 2017] 7(2). Disponible en: http://www.index-f. com/lascasas/documentos/lc0600.pdf

46. Muñoz Devesa A, Morales Moreno I, Bermejo Higuera JC, Galán González Serna JM. La Relación de ayuda en Enfermería. Index Enferm (Gran) 2014; 23(4):229-233.

47. Schenker Y, Crowley Matoka M, Dohan D, Tiver GA, Arnold RM, White DB. I don't want to be the one saying 'we should just let him die': intrapersonal tensions experienced by surrogate decision makers in the ICU. PubMed [Internet]. 2012 [Consultado el 18 de Marzo de 2017]; 27(12):1657-1665. Disponible en: https://www.ncbi.nlm.nih.gov/pubmed/23011253

48. Achury DM, Achury Beltrán LF, Ramírez Cárdenas AM. La familia y las visitas en las unidades de cuidado intensivo. The world of Critical care nursing. [Internet] 2011. [Consultado el 16 de marzo de 2017]; 8(1):2-8. Disponible en: http://connectpublishing.org/assets/journals/8 1_ 1.pdf

49. Achury DM, Castaño Riaño HM, Gómez Rubiano LA, Guevara Rodríguez NM. Calidad de vida de los cuidadores de pacientes con enfermedades crónicas con parcial dependencia. Investigación en 
Enfermería: Imagen y Desarrollo [Internet]. 2011 [Consultado el 05 de marzo de 2017]; 13(1):27-46 Disponible en: http://www.redalyc.org/articulo.oa?id=145221282007

50. Errasti Ibarrondo B, Tricas Sauras S. La visita flexible en las unidades de cuidados intensivos: beneficios para los familiares del paciente crítico. Enfer. Intensiv. [Internet]. 2012 [Consultado el 29 abril de 2017]; 23(4):179-188. Disponible en: http://www.elsevier.es/es-revista-enfermeria-intensiva142-articulo-la-visita-flexible-las-unidades-S1130239912000715?redirectNew=true
ISSN-PRINT

1794-9831

E-ISSN 2322-7028

Vol. 15 No. 2

Jul - Dic 2018

Cúcuta, Colombia 